\section{LA-UR-05-6005}

Approved tor public release; distribution is unlimited.
QA:N/A

8-10-2005
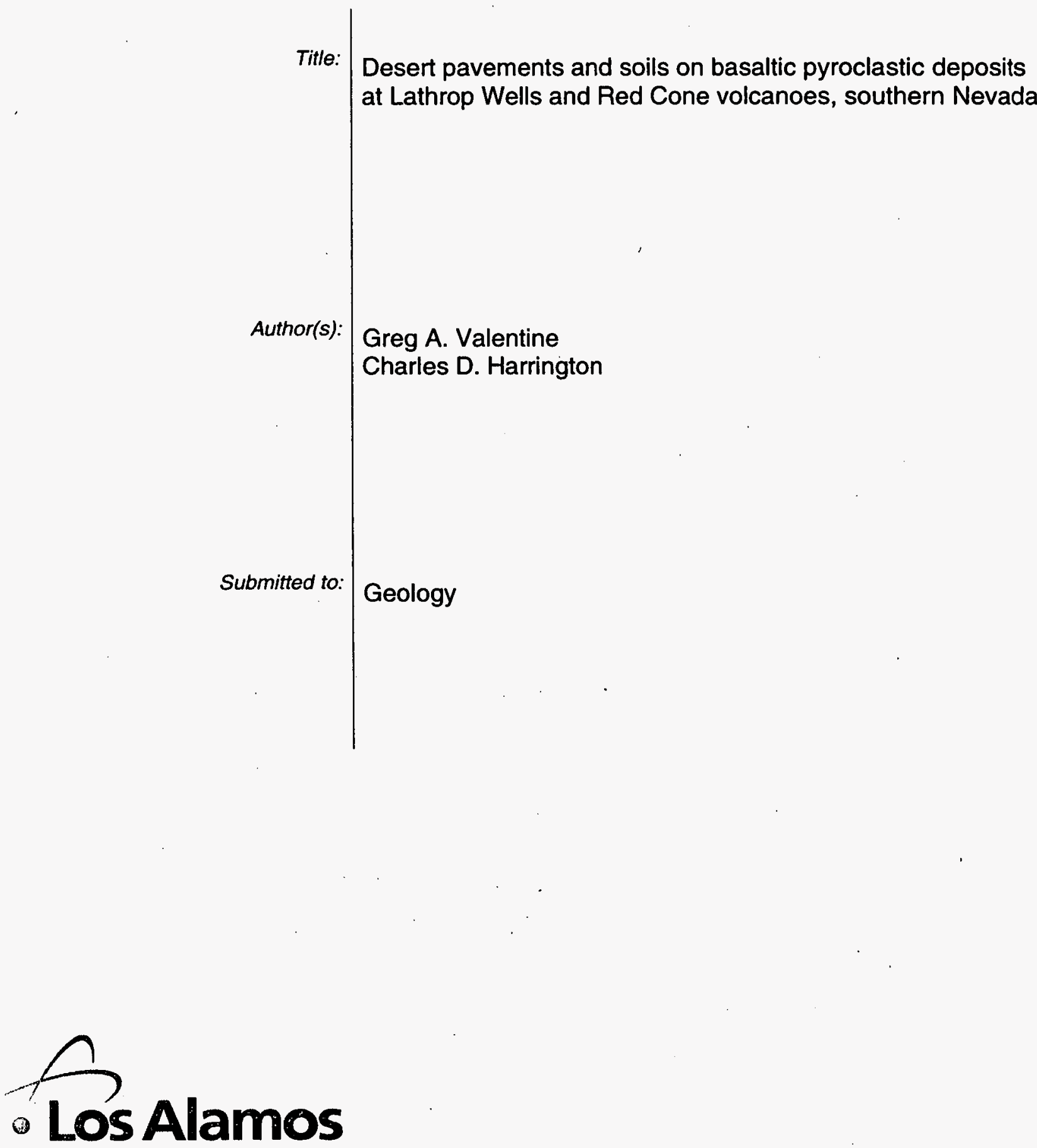

NATIONAL LABORATORY

Los Alamos National Laboratory, an affirmative action/equal opportunity employer, is operated by the University of Calitornia for the U.S. Department of Energy under contract W-7405-ENG-36. By acceptance of this article, the publisher recognizes that the U.S. Government retains a nonexclusive, royalty-free license to publish or reproduce the published form of this contribution, or to allow others to do so, for U.S. Government purposes. Los Alamos National Laboratory requests that the publisher identify this article as work performed under the auspices of the U.S. Department of Energy. Los Alamos National Laboratory strongly supports academic freedom and a researcher's right to publish; as an institution, however, the Laboratory does not endorse the viewpoint of a publication or guarantee its technical correctness. 


\title{
Desert pavements and soils on basaltic pyroclastic deposits at Lathrop Wells and Red Cone volcanoes, southern Nevada
}

\author{
Greg A. Valentine ${ }^{1}$ and Charles D. Harrington \\ Earth and Environmental Sciences Division, Mail Stop D462, Los Alamos National \\ Laboratory, Los Alamos, NM 87545 USA \\ 'Email: gav@lanl.gov
}

\begin{abstract}
Formation of desert pavement and accretionary soils are intimately linked in arid environments such as the Mojave Desert. Well-sorted fallout scoria lapilli at Lathrop Wells (75-80 ky) and Red Cone ( 1 Ma) volcanoes (southern Nevada) formed an excellent starting material for pavement, allowing infiltration of eolian silt and fine sand that first clogs the pore space of underlying tephra and then aggrades and develops vesicular A (Av) horizons. Variations in original pyroclast sizes provide insight into minimum and maximum clast sizes that promote pavement and soil formation: pavement becomes ineffective when clasts can saltate under the strongest winds, while clasts larger than coarse lapilli are unable to form an interlocking pavement that promotes silt accumulation (necessary for Av development). Contrary to predictions that all pavements above altitudes of $\sim 400 \mathrm{~m}$ would have been "reset" in their development after late Pleistocene vegetation advances (about $15 \mathrm{ka}$ ), the soils and pavements show clear differences in maturity between the two volcanoes. This indicates that either the pavements/soils develop slowly over many 10,000 's of years and then are very stable, or that, if they are disrupted by vegetation advances, subsequent pavements are reestablished with successively more mature characteristics.
\end{abstract}


Keywords: desert pavement, soil, scoria, eolian

\section{INTRODUCTION}

An important surface process in deserts is the concurrent formation of accretionary soil and desert pavement formed of a one-clast-thick layer of closely-spaced fragments (pebbles, or lapilli if the clasts are of volcanic origin). A widely accepted model involves the deposition of eolian silt and fine sand around coarser clasts (derived from weathering of initial rock surfaces or larger clasts, or by overland flow; Wells et al., 1985; Al-Farraj and Harvey, 2000; McFadden et al., 2005; Williams and Zimbelman, 1994). Cycles of wetting and drying (causing swelling and shrinking if the eolian material contains clay minerals) and/or freeze-thaw action results in fine-grained material working its way beneath the coarse clasts and lifting of the coarse clasts atop a thickening layer of eolian silt and fine sand (McFadden et al., 1987, Wells et al., 1995). Pedogenic processes in the silt/fine sand progress to form a vesicular horizon (Av) and, given time, features characteristic of increasingly mature soils (e.g., Wells et al., 1985; McFadden et al., 1987; Anderson et al., 2002; Wood et al., 2005). Ecosystem characteristics also play a key role; relatively dense plant communities and associated bioturbation act to "churn" the surface materials, mixing potential pavement-forming clasts into the underlying eolian sediment. Quade (2001) concluded that any pavement above an altitude of about $400 \mathrm{~m}$ in the Mojave Desert would have essentially had its level of development reset since the end of the most recent vegetation advance, $\sim 15 \mathrm{ka}$. We describe desert pavements and soils formed on scoria deposits at Lathrop Wells and Red Cone volcanoes (southern Nevada) that provide insight into the role of initial clast size in the formation of desert pavement, allow us to test whether pavement and soil maturity has been reset by 
latest Pleistocene climate evolution, and provide an initial framework for the formation of desert soils on well-sorted, porous pyroclastic deposits'.

\section{Lathrop Wells and Red Cone volcanoes}

The hawaiitic (Vaniman et al., 1982) Lathrop Wells volcano (Fig. 1A) has a total eruptive volume of about $0.09 \mathrm{~km}^{3}$ and consists principally of: (1) a 140 m high scoria cone that is being rapidly quarried, (2) two aa lava flow fields, one of which flowed south-southeastward (south lava field), and a second that flowed initially northeastward from the cone and then wrapped toward the south (northeast lava field), and (3) a scoria lapilli and ash fallout deposit that might have extended as far as $20 \mathrm{~km}$ north of the cone (Perry et al., 1998; BSC, 2004a). The age of this volcano, although controversial at one time (e.g., Crowe et al., 1982; Wells et al., 1990, 1992; Turin et al., 1991, 1992) is now well established at 75-80 ky (Zreda et al., 1993; Heizler et al., 1999).

Red Cone (Figure 1B), located about $8 \mathrm{~km} \mathrm{~N}$-NW of Lathrop Wells volcano, is an older $\left({ }^{40} \mathrm{Ar} /{ }^{39} \mathrm{Ar}\right.$ ages between $0.92-1.10 \mathrm{Ma}$; Perry et al., 1998; BSC, 2004b) volcanic center of similar composition (Vaniman et al., 1982) and volume to the Lathrop Wells volcano, also with two lava flow fields, and with the remnant of a main cone that marks the vent area. Because of its age it is extensively eroded and drainage networks have developed that extend from lava flow margins to the upper slopes of the remnant cone.

\section{Desert pavements on scoria-covered lava surfaces}

The surface of most of the south lava field at Lathrop Wells volcano is a onetephra-clast-thick layer (pavement) that is underlain by a $20-40 \mathrm{~cm}$ zone of silt and fine quartzose sand mixed with volcanic clasts that rapidly grades downward into primary fallout scoria deposits (1-3 m thick, depending upon distance from the cone) from violent 
Strombolian eruptions that blanketed the south lava after it was emplaced early in the eruption sequence (Figure 2A; Valentine et al., 2005). Locally the top few centimeters of the mixed zone form a weakly developed vesicular A (Av) horizon indicative of early stages of soil development (e.g., Wells et al., 1995; McFadden et al., 1987). The pavement is composed mainly of well-sorted, small scoria lapilli that typically are smaller in one dimension than in the other two. These form patches (with areal dimensions of tens of centimeters) of relatively tightly-fitted clasts with very little exposure of underlying sand/silt; the patches are separated by similar-sized areas of looser-fitting pavement clasts and more exposure of underlying eolian materials. This patchy characteristic of the tightness of the pavement indicates that it is still in its formational stages and is easily scarred. Close to steep-sided lava surface features and mounds of coarse cone material (rafted atop the lava flows to their current locations) that protrude above the fallout tephra, the pavement clasts are bimodal in size (Figure 2B), with an additional component of multi-centimeter-sized clasts that have weathered off the lava or paleotopographic highs (Wells et al., 1985). Unlike pavement clasts at Red Cone, those at Lathrop Wells that we observed do not have reddened undersides.

While the northeast lava field at Lathrop Wells volcano likely formed contemporaneously with violent Strombolian activity late in the eruptive sequence (Valentine et al., 2005), most of its surface was not covered with lapilli-size fallout clasts; its features seem similar to the southern flow except that they expose much more of the original lava surface. The northeast flow field rafted much less cone or proximal pyroclastic material along its top, relative to the south flow field. An exception is a small area (about $10^{4} \mathrm{~m}^{2}$ ) near the lava field's northeastern margin, which has desert pavement 
composed of well-sorted, small scoria lapilli (typically $0.5-2 \mathrm{~cm}$ ) that is similar to that described above. We interpret the lapilli in this area to have accumulated by fallout on the surface of the flow much closer to the cone and subsequently rafted along the flow top to its current location. It is worth noting that a large fraction of the northeast lava field is covered with active sand dunes but this small scoria-paved area has a relatively flat topography similar to the paved parts of the south lava field (see comparison in Figure $2 \mathrm{C}$ ). We infer that this difference at least partly reflects the stabilizing influence of pavement-forming scoria with respect to eolian transport and deposition.

Although Red Cone is highly eroded compared to Lathrop Wells volcano, there are local areas on the flow surfaces that appear to have been stable and relatively uneroded. The original surface features of the Red Cone lavas were very similar to those described at Lathrop Wells, but with more abundant rafted, coarse-grained cone material as well as apparently being at least partly blanketed with well-sorted, scoria lapilli fallout. Figure 2D shows a pavement composed of materials similar to those formed on scoria fallout deposits at Lathrop Wells, but at a more advanced stage of development. This pavement is bimodal, being dominated by well-sorted scoria lapilli, typically with a slightly flattened shape, with a smaller component of coarse lapilli-sized clasts. The well-sorted nature of the pavement matrix indicates that its clasts originated as fallout rather than by mechanical weathering of coarser materials or a lava surface, a mechanism that would likely result in a wider range of clast sizes (we infer that the less abundant, larger clasts were weathered off nearby lava highs). The pavement is extremely tight, with only a few percent of exposure of underlying soil. Beneath the pavement is a well developed, highly vesicular A horizon (17 cm thick) that is underlain by a reddened 
(oxidized) horizon, the depth of which is undetermined. Such reddened (B?) horizons formed when the climate was significantly wetter than today, as during either glacial or glacial transitional times. Many pavement-forming clasts have reddened undersides and distinct desert varnish on their exposed surfaces.

\section{Minimum and maximum clast size for pavement development}

Around most quadrants the Lathrop Wells fallout sheet extends onto alluvial surfaces and has been buried by later sediments. However, to the east-southeast of the cone the grain size of fallout tephra decreases quite rapidly so that by $500-600 \mathrm{~m}$ from the cone base the fallout appears to have decreased to primarily coarse ash size (1-2 mm).

Local flat patches and swales (typically $\sim 100 \mathrm{~m}^{2}$ in area) of fine sand and silt are capped with a loose, single-clast layer of coarse ash. This coarse ash serves a role that is like a pavement in that it seems to stabilize the surface, but it also is locally concentrated into ripple forms (wavelengths $\sim 20 \mathrm{~cm}$, amplitudes $\sim 5 \mathrm{~mm}$ ), indicating that it is subject to saltation during strong winds. Smaller scoria clasts would be transported in dunes as are other eolian deposits nearby. This seems to indicate that the lower limit of clast size for pavement formation is simply that at which the clasts can be transported by the strongest winds and may not be controlled by internal pedogenic processes.

A maximum clast size above which desert pavement formation is not favored may be illustrated at the top of a mound of rafted cone material at Red Cone. Here the clasts are coarse lapilli and small blocks (probably broken fragments of originally larger fluidal bombs) and bombs, with a variety of shapes (Figure 2E). Below these surface clasts is a $\sim 13 \mathrm{~cm}$ thick deposit of fine sand with very little silt and no vesicular horizon, and beneath the sand is an indurated zone of carbonate. Pavements and underlying soils such 
as in Figure $2 \mathrm{D}$ exist within $\sim 50 \mathrm{~m}$ of this site, so there can be no appreciable variation in quantity or size distribution of eolian sediment supply. Instead, the coarse, irregularlyshaped clasts cannot form a tight pavement. This promotes infiltration of more sandsized sediment compared to a very tight pavement that allows infiltration mainly of silt. The accreting soil therefore has lower clay content and is less amenable to volume changes during wetting and drying, which are important processes in developing an Av horizon as well as pavement development. This example indicates that clasts larger than large lapilli or small blocks may not support development of a tight desert pavement and Av horizon, although as mentioned above clast shape likely plays an important role as well.

\section{Pavement development "clock" not (simply) reset after late Pleistocene}

The difference in pavement and soil maturity between Lathrop Wells and Red Cone volcanoes (compare Figures 2B and 2D) complicate Quade's (2001) conclusion that pavements above an altitude of $\sim 400 \mathrm{~m}$ in this region were "reset" in terms of their development prior to the latest Pleistocene. These volcanoes are both at altitudes of 800 $900 \mathrm{~m}$ and the pavements we describe are composed of similar starting materials (dominantly well-sorted, small to medium scoria lapilli). Yet despite these common conditions, there are clear differences in the maturity of the pavements (e.g., tightness, reddening of clast undersides, varnishing of clast tops) and underlying soils (development and thickness of Av and oxidized (B?) horizons). One possibility is that Red Cone has undergone many more cycles of pavement/soil development followed by bioturbation and churning during wet periods. Each time the region entered an arid period of time, desert pavement was re-established but with successively more "mature" materials. In this way 
it may be possible that a pavement on an older surface may be the same age as that on a younger (but pre-Holocene) surface, but with more mature characteristics. Another possibility is that the pavements at Red Cone formed during the first 100,000 years or so after eruptive emplacement and have been stable and relatively vegetation free since then. In this model Lathrop Wells pavements are still in a developing stage and eventually will achieve the same degree of permanence as those at Red Cone. The latter model assumes that all other variables, especially the characteristics of the eolian flux (see Reheis et al., 1995), are similar at the two volcanoes and have been through time. Surface exposure dating (e.g., Wells et al., 1995) should be able to determine if pavement clasts have been at the surface since the time of primary volcanic emplacement, as opposed to experiencing temporary periods of shallow burial (e.g., a few cm), although Quade (2001) questions whether cosmogenic surface dating of pavement clasts is able to resolve this question. If reddening of a pavement clast's underside is a function of pavement age (see, for example, McFadden et al., 1987), the difference in this feature between Lathrop Wells and Red Cone would indicate that their current pavements are of different ages and that they were not both reset at latest Pleistocene time.

\section{Summary}

Based upon our observations at Lathrop Wells and Red Cone volcanoes, there appear to be distinct stages in development of desert pavements and associated soils on basaltic pyroclastic deposits (Figure 3). In some ways these stages are similar to those described by Wells et al. (1985) for evolution of lava flow surfaces. First, eolian fine sand and silt accretes on the surface and is transported downward into the highly porous pyroclastic material by infiltrating rain (assisted by bioturbation) and by volume changes 
during wetting and drying. This process forms a mixed scoria, fine sand and silt horizon such as at Lathrop Wells. The topmost scoria clasts immediately form a pavement material. For a loose scoria deposit the phase during which eolian sediments infiltrate the scoria is a prerequisite to actually aggrading the surface in that the sediments eventually clog the original porosity (although some aggradation can occur if the influx of eolian sediment exceeds the rate at which it can be transported downward); once this has been achieved further eolian accretion takes place as a thickening layer of fine sand and silt that both lifts and is protected by the pavement-forming clasts. Continued accretion and pedogenic processes tighten the pavement. The tighter pavement forms a natural sieve that favors accretion of finer-grained sediment (silt), in turn increasing the clay content and accelerating the maturation of the soil. If the original scoria clasts are too small (vulnerable to eolian mobilization) eolian sediments will not accumulate in a stable accreting deposit; if the starting clasts are too large and irregularly shaped (thus not able to form a tight pavement that favors silt infiltration) they will not support the development of mature soil horizons.

A final note relates to the apparently young surface morphology of the Lathrop Wells cone, with few if any erosional rills, which led Wells et al. (1990) to suggest an age of about $20 \mathrm{ka}$ (or less). Because of the eruptive processes at Lathrop Wells the upper scoria cone-forming deposits are entirely composed of loose, nonwelded, lapilli and block sized scoria (Valentine et al., 2005), unlike many cones that have much coarser and partly to completely welded materials. The loose scoria is highly porous and permeable such that heavy rains simply soak into the surface without developing runoff. It is only after appreciable eolian sediment infiltration has clogged this porosity (e.g., Figure 3B), 
and perhaps supported the development of indurated carbonate horizons, that runoff can nucleate and form rills and gullies. Thus a cone with an eruption history similar to that of Lathrop Wells volcano may not display rills for many tens of thousands of years, while cones built by eruptions that produced much coarser and welded material may develop runoff and erosional features more rapidly.

\section{Acknowledgements}

We thank Frank Perry and Don Krier for reviewing the manuscript, Jon Pelletier for very useful discussions, and Mike Cline for his support of this work, which was funded as part of the U.S. Department of Energy's Yucca Mountain Project, via BechtelSAIC, LLC.

\section{References}

Al-Farraj, A., Harvey, A.M., 2000, Desert pavement characteristics on Wadi terrace and alluvial fan surfaces: Wadi Al-Bih, U.A.E. and Oman: Geomorphology, v. 35, p. $279-297$.

Anderson, K., Wells, S., and Graham, R., 2002, Pedogenesis of vesicular horizons, Cima Volcanic Field, Mojave Desert, California: Soil Science Society of America Journal, v. 66, p. $878-887$.

BSC (Bechtel SAIC Company), 2004a, Characterize eruptive processes at Yucca Mountain, Nevada: Las Vegas, Nevada, Bechtel SAIC Company, ANL-MGR-GS000002 REV 02.

BSC (Bechtel SAIC Company), 2004b, Characterize framework for igneous activity at Yucca Mountain, Nevada: Las Vegas, Nevada, Bechtel SAIC Company, ANL-MGRGS-000001 REV 02. 
Crowe, B.M., Johnson, M.E., and Beckman, R.J., 1982, Calculation of the probability of volcanic disruption of a high-level radioactive waste repository within southern Nevada, USA: Radioactive Waste Management and the Nuclear Fuel Cycle, v. 3, p. 167-190.

Golembek, M.P., Arvidson, R.E., Bell III, J.F., Christensen, P.R., Crisp, J.A., Crumpler, L.S., Ehlmann, B.L., Fergason, R.L., Grant, J.A., Greeley, R., Haldemann, A.F.C., Kass, D.M., Parker, T.J., Schofield, J.T., Squyres, S.W., and Zurek, R.W., 2005, Assessment of Mars Exploration Rover landing site predictions: Nature, v. 436, p. 4448.

Heizler, M.T., Perry, F.V., Crowe, B.M., Peters, L., and Appelt, R., 1999, The age of the Lathrop Wells volcanic center: $\mathrm{An}{ }^{40} \mathrm{Ar} /{ }^{39} \mathrm{Ar}$ dating investigation: Journal of Geophysical Research, v. 104, p. 767-804, doi: 10.1029/1998JB900002.

McFadden, L.D., Wells, S.G., and Jercinovich, M.J., 1987, Influences of eolian and pedogenic processes on the origin and evolution of desert pavements: Geology, v. 15, p. 504-508.

McFadden, L.D., Eppes, M.C., Gillespie, A.R., and Hallet, B., 2005, Physical weathering in arid landscapes due to diurnal variation in the direction of solar heating: Geological Society of America Bulletin, v. 117, p. 161-173.

Perry FV, Crowe BM, Valentine GA, Bowker LM, eds., 1998, Volcanism studies: final report for the Yucca Mountain Project: Los Alamos, New Mexico, Los Alamos National Laboratory, LA-13478, $554 \mathrm{pp}$.

Quade, J., 2001, Desert pavements and associated rock varnish in the Mojave Desert: How old can they be?: Geology, v. 29, p. 855-858. 
Reheis, M.C., Goodmacher, J.C., Harden, J.W., McFadden, L.D., Rockwell, T.K., Shroba, R.R., Sowers, J.M., and Taylor, E.M., 1995, Quaternary soils and dust deposition in southern Nevada and California: Geological Society of America Bulletin, v. 107, p. 1003-1022.

Turin, B.D., Champion, D.E., and Fleck, R.J., $1991,{ }^{40} \mathrm{Ar} /{ }^{39}$ Ar age of the Lathrop Wells volcanic center, Yucca Mountain, Nevada: Science, v. 253, p. 654-657.

Turin, B.D., Champion, D.E., and Fleck, R.J., 1992, Measuring the age of the Lathrop Wells volcanic center at Yucca Mountain: Response to comment on ${ }^{40} \mathrm{Ar} /{ }^{39} \mathrm{Ar}$ age of the Lathrop Wells volcanic center, Yucca Mountain, Nevada: Science, v. 257, p. 556558.

Valentine, G.A., Krier, D., Perry, F.V., and Heiken, G., 2005, Scoria cone construction mechanisms, Lathrop Wells volcano, southern Nevada, USA: Geology, v. 33, p. 629630.

Vaniman, D.T., Crowe, B.M., and Gladney, E.S., 1982, Petrology and geochemistry of hawaiite lavas from Crater Flat, Nevada: Contributions to Mineralogy and Petrology, v. 80 , p. $341-357$, doi: $10.1007 /$ BF00378007.

Wells, S.G., Dohrenwend, J.C., McFadden, L.D., Turin, B.D., and Mahrer, K.D., 1985, Late Cenozoic landscape evolution on lava flow surfaces of the Cima volcanic field, Mojave Desert, California: Geological Society of America Bulletin, v. 96, p. 15181529.

Wells, S.G., McFadden L.D., Renault, C.E., and Crowe, B.M., 1990, Geomorphic assessment of late Quaternary volcanism in the Yucca Mountain area, southern 
Nevada: Implications for the proposed high-level radioactive waste repository: Geology, v. 18, p. 549-553.

Wells, S.G., Crowe, B.M., and McFadden, L.D., 1992, Measuring the age of the Lathrop Wells volcanic center at Yucca Mountain: Comment on ${ }^{40} \mathrm{Ar} /{ }^{39} \mathrm{Ar}$ age of the Lathrop Wells volcanic center, Yucca Mountain, Nevada: Science, v. 257, p. 555-556.

Wells, S.G., McFadden, L.D., Poths, J., and Olinger, C.D., 1995, Cosmogenic ${ }^{3} \mathrm{He}$ surface-exposure dating of stone pavements: implications for landscape evolution in deserts: Geology, v. 23, p. 613-616.

Williams, S.H., and Zimbelman, J.R., 1994, Desert pavement evolution: an example of the role of sheetflood: Journal of Geology, v. 102, p. 243-248.

Wood Y.A., Graham, R.C., and Wells, S.G., 2005, Surface control of desert pavement pedologic process and landscape function, Cima Volcanic field, Mojave Desert, California: Catena, v. 59, p. 205-230.

Zreda, M.G., Phillips, F.M., Kubik, P.W., Sharma, P., and Elmore, D., 1993, Cosmogenic

${ }^{36} \mathrm{Cl}$ dating of a young basaltic eruption complex, Lathrop Wells, Nevada: Geology, v. 21, p. $57-60$.

\section{Figures}

Figure 1. (A) Air photo of Lathrop Wells volcano, showing cone and two lava flow

fields. Symbols A and B mark locations of photos in Figures 2A and B, respectively. (B) Air photo of Red Cone volcano, showing cone remnant and two lava flow fields. Symbols D and E mark locations of photos in Figures 2D and 2E, respectively. 
Figure 2. Examples of different surface deposits on top of lava flows at Lathrop Wells volcano. (A) Vertical quarry exposure of fallout scoria beds, mixed zone of infiltrated eolian silt/fine sand and scoria at its top, and bimodal pavement on top (here the coarse clasts are fragments from a nearby exposure of Miocene silicic tuff). (B) Bimodal, developing desert pavement on southern lava field formed of clasts from the fallout tephra (well-sorted small lapilli) and from larger fragments weathered off a nearby lava surface that protrudes above the pyroclastic deposits. (C) Contrasting surface morphology at Lathrop Wells volcano for areas with and without scoria lapilli as starting materials - south lava surface (left of electrical pole) has a developing lapilli pavement, while northeast lava surface (right of pole) is largely covered with active dunes. (D) Oblique view of soil pit showing relatively mature desert pavement at Red Cone dominated by well-sorted fallout scoria lapilli, and underlying soil with upper Av and underlying reddened horizons. (E) Poor pavement development at Red Cone where source materials are coarse, irregularly shaped, moderately to poorly sorted clasts. Note larger fraction of open space. Underlying material is mainly fine sand with a hard carbonate zone at $13 \mathrm{~cm}$ depth.

Figure 3 - sketches of hypothetical stages of soil/pavement development on scoria surfaces. (A) Initial, well sorted scoria fallout deposit. (B) Accumulation of eolian fine sand and silt with infiltration into top of porous scoria deposit and initial pavement. (C) Aggradation of eolian material by accretion above original scoria deposit, but capped by desert pavement and development of soil horizons. 

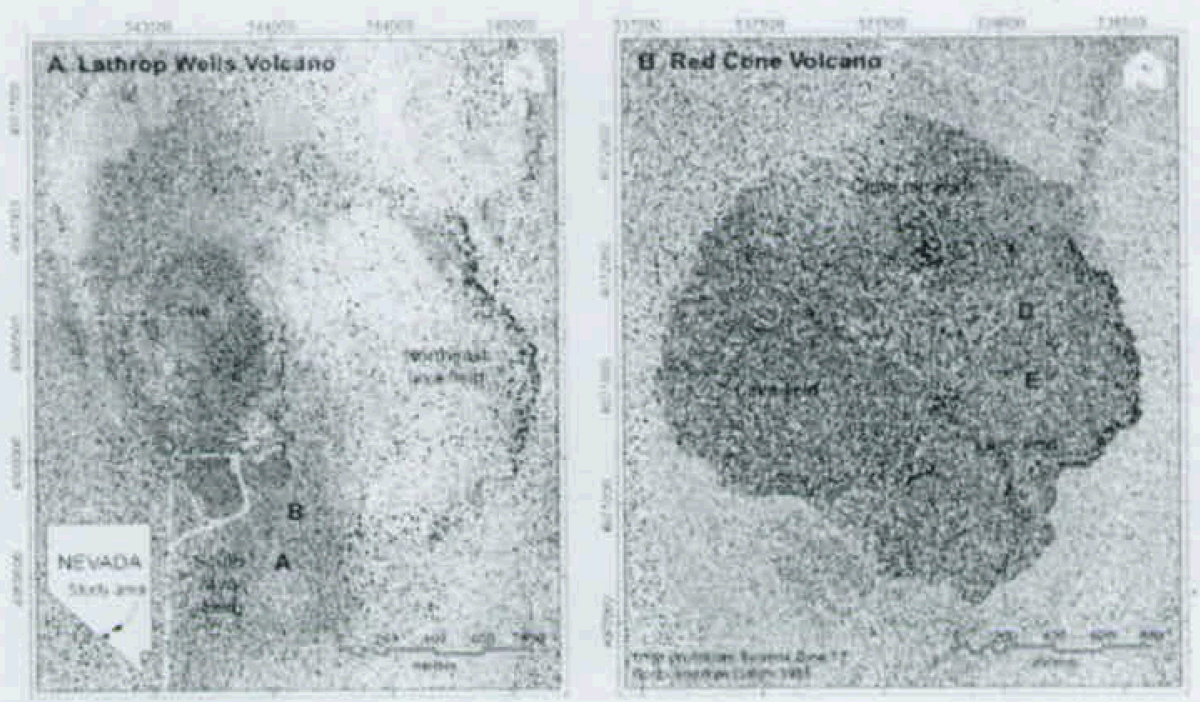

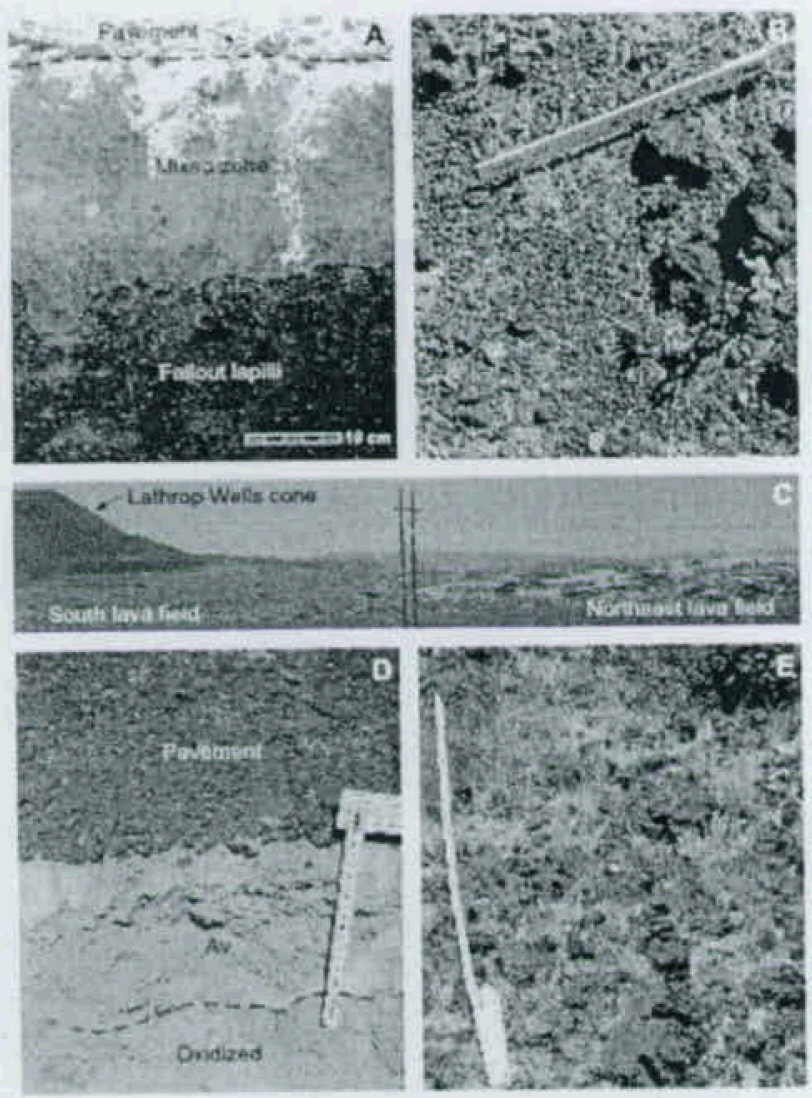


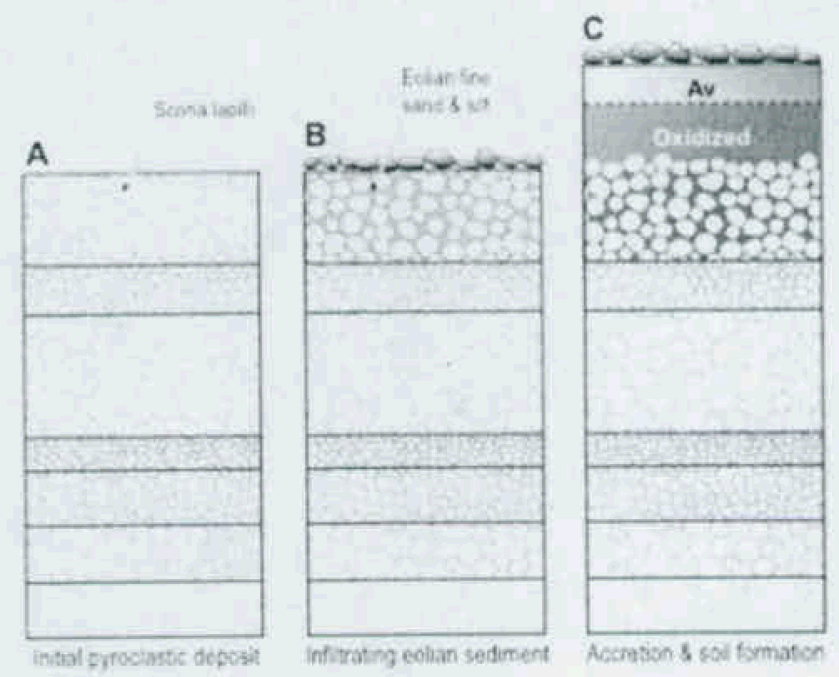

